\title{
GEOGRAFISKA
} ANNALER

SERIES A PHYSICAL GEOGRAPHY

\section{Impacts of land abandonment and climate variability on runoff generation and sediment transport in the Pisuerga headwaters (Cantabrian Mountains, Spain)}

\begin{tabular}{|c|c|}
\hline Journal: & Geografiska Annaler: Series A, Physical Geography \\
\hline Manuscript ID & Draft \\
\hline Wiley - Manuscript type: & Original Article \\
\hline Date Submitted by the Author: & $\mathrm{n} / \mathrm{a}$ \\
\hline Complete List of Authors: & $\begin{array}{l}\text { Pisabarro, Alfonso; Universidad de Valladolid, Geography } \\
\text { Pellitero, Ramón; Universidad del Pais Vasco, Geografía, Prehistoria y } \\
\text { Arqueología } \\
\text { Serrano, Enrique; Universidad de Valladolid, Geography } \\
\text { Lopez-Moreno, Juan Ignacio; Instituto Pirenaico de Ecologia }\end{array}$ \\
\hline Keywords: & Cantabrian Mountains, Global Change, Depopulation \\
\hline Abstract: & $\begin{array}{l}\text { The Atlantic mountains of Spain are suffering a strong landscape change } \\
\text { due to a widespread and intensive emigration to urban areas since the } \\
1950 \text { 's. This process, perfectly extensible worldwide in an imminent } \\
\text { future, is dominated by urban societies, and leads to deep landscape } \\
\text { changes in which crop fields and grasslands are abandoned and } \\
\text { progressively covered by forest and shrubs. These dynamics have caused } \\
\text { in turn a decrease in the runoff and a general slowdown of } \\
\text { geomorphological processes. The impacts of land cover change have been } \\
\text { simultaneous to an irregularity in precipitation and significant increase of } \\
\text { temperatures. With this background, this paper assesses in detail the } \\
\text { impact of landscape change occurred over the last decades (20th and } 21 \text { th } \\
\text { centuries) on the water and sediment yield in the Pisuerga catchment } \\
\text { headwaters (Cantabrian mountains, N Spain). } \\
\text { We analysed the different components of Global Change in a catchment of } \\
233 \text { km2 extent, that has passed from } 15 \text { to } 2 \text { habitants/km2, from } \\
\text { multiple data sources. Evolution of land use and land cover was } \\
\text { reconstructed from old manuscripts, aerial photographs, and remote } \\
\text { sensing. The climatic parameters have been studied through } \\
\text { meteorological stations and historical data, and the hydrological and } \\
\text { sedimentological responses over time are based on available runoff data } \\
\text { and sedimentological analysis. } \\
\text { Our results show a significant decrease in water and sediment transport } \\
\text { mainly driven by vegetation increase occurred in a non-linear way, more } \\
\text { intense immediately after abandonment. This fact opens the opportunity to } \\
\text { control more accurately water resources in Mediterranean catchments } \\
\text { through land use management. }\end{array}$ \\
\hline
\end{tabular}




\section{SCHOLARONE $^{\mathrm{m}}$}

Manuscripts 
1 I. Introduction.

2 Changes to the physical environment caused by human settlements are inherent to the

3 societies that occupy or exploit it. This idea was accepted long ago (Marsh, 1864) and has been

4 widely developed since (Sauer, 1925, Thomas, 1956, Turner, 1990, Vitousek, 1992, Goudie,

5 2013). Nevertheless, the urbanization of central areas and emigration trends have created a new paradigm in abandoned areas, which were previously intensely humanized. The European

7 landscape is undergoing increased naturalization, vegetation colonization and densification

8 (Pereira and Navarro, 2015), which obviously influences water resources even more than does

9 climate change (Church et al. 2009). The direct relationship between vegetation and water

10 drainage has already been described elsewhere for the Iberian Peninsula, e.g. in tributary

11 catchments of the river Ebro mainly from the Pyrenees (Beguería et al., 2003, Gallart and

12 Llorens, 2004, García-Ruiz et al., 2015, Lasanta et al. 2010; López-Moreno et al., 2006, 2011,

13 2014; Vicente-Serrano et al. 2014), and worldwide (Good et al., 2015). Research of this kind is

14 of the utmost importance in areas such as the Iberian Peninsula where water resources are

15 scarce. García-Ruiz et al. (2011) predict that for the period 2040-2070 between 100 and 200

$16 \mathrm{~mm}$ in hydrological balance (P-T) will be lost, based on data from the 1960-1990 period. Some

17 authors commonly relate these trends with erosion rates and geomorphic changes, e.g. García-

18 Ruíz et al., (2010); Sanjuán et al. (2014).

19 The hydrographic basin is usually the most appropriate spatial scale to relate many of the 20 global changes to the water and sediment inputs received (Slaymaker and Embletton-Hamann, 21 2009). With a few exceptions (Morán-Tejeda et al., 2010; Ceballos-Barbancho, 2008), research 22 of this kind has not been generally considered for large areas of the Cantabrian Mountains or 23 the Duero/Douro catchment. This is a key feature of water resources in the Duero/Douro 24 catchment, however, in which the waters supplied by just four rivers flowing from the 25 Cantabrian Range (Órbigo, Esla, Carrión and Pisuerga) contribute 44.5\% of the total 
Duero/Douro flow. Moreover, these waters irrigate around 280,000 hectares of agricultural land in the Castilla y León region alone (CHD, 2015, p. 102), supply water to hydroelectric plants that produce $1400 \mathrm{MW} / \mathrm{yr}$. of electrical power and fresh water to over 800,000 people (CHD, 2015, p. 89).

This paper aims to demonstrate that lack of use and management in a territory produces huge changes in its physical environment. Specifically, our particular research is focused on the loss of hydric resources and fall in sediment transport as a result of land cover transformation.

\section{Study site}

The entire Pisuerga catchment headwaters $\left(233 \mathrm{~km}^{2}\right)$ are above 1000 meters, with mountain peaks at over 2,000 meters (Figure 1). The Requejada reservoir $\left(66.4 \mathrm{hm}^{3}\right.$ ) is at the outlet of the catchment, the dam of which was built between the 1920's and 1940 for irrigation supply and hydropower production. The catchment lies to the North of the province of Palencia on the southern face of the Cantabrian Range. This is a humid area where total annual precipitation is 800 to $>1400 \mathrm{~mm}$ (Ortega and Morales, 2015), much of which falls as snow.

From a climatic perspective, this area is in transition between an Atlantic and a Mediterranean climate, with high annual precipitation but a clear arid season in summer. These conditions favor the growth of oak (Quercus sp.) on the southern slopes and beech (Fagus sylvatica) on the Northern slopes. The entire area is within the eastern part of Fuentes Carrionas y Fuente el

45 Cobre Natural Park.

Settlers from the Cantabrian Coast in the $8^{\text {th }}$ and $9^{\text {th }}$ centuries populated this area, intensively transforming its landscape. Subsistence agriculture with extensive cattle farming and forest use lasted until the XIX century, when some coal deposits were found and mined until the 1960s - 70s. Meanwhile, an increasing emigration process began from the late 1940 s mainly to 
the benefit of the industrial centers on the $\mathrm{N}$ coast (e.g. Bilbao area) (Figure 1). There are currently around 500 people living in this area, distributed among 18 small villages.

\section{Methodology}

The method fits well with the Alto Pisuerga basin, at the outlet of which there is a reservoir that allows the hydric resources of the basin to be monitored. Thanks to this fact the present article is able to explain the relationships among the changes in land use, climate variability, flow rate and sedimentary load since the reservoir came into operation. The time scale begins with the commencement of reservoir water flow measurements. This is roughly the same time frame as the beginning of emigration from the region.

The first part of the results focuses on the change in land cover over time, for which different resources were used. The most ancient systematic estimation of land use and vegetation cover in the catchment dates back to 1749 , thanks to the Cadaster de la Ensenada, which was made by means of a questionnaire sent to each settlement in Spain. The responses to changes in cover given in different unit systems were converted to the decimal metric system (Castaño, 2015). The 1955 land cover map was obtained from aerial imagery provided by the U.S. air force, which has recently been orthorectified by the Technological Institute of Agriculture of Castilla y Leon (ITACYL). The 1972 landcover map was drawn up from a supervised classification using Landsat satellite imagery. The 1997 map comes from the 1:50,000 scale Spanish Forestry Map and the 2011 map was acquired from the Spanish Landcover Information System (SIOSE). Finally, the last 2017 landcover map has been drawn up from a supervised classification of ESA Sentinel 2A-MSI imagery.

The second group of results has two parts, one corresponding to climate and water flow evolution between 1955 and 2014 and the other featuring the volumetric quantification of hydrological deficit (D) and potential evapotranspiration (PET). Climate parameters were taken from the meteorological stations managed by the Spanish Meteorological Agency (AEMET), 
which have continuous records since 1955 (Table 1), either in the study area or its close vicinity. Gaps in the series were filled by linear interpolation using the best correlated station. Data quality procedures were also applied, and some spurious outliers were identified and removed. Water flow data from the Requejada reservoir inputs (x: 375489; y: 4750756) come from the Duero Hydrographic Confederation's dataset and span from 1959 to 2016.

In this first stage, a linear regression was performed between regional series of climate data and water flow to find the influence of non-climatic factors (likely associated to land cover change) on the hydrological response of the catchment. Using the residual values of the linear regression the temporal periods with non-climatic influence can be inferred. This procedure has been widely applied, e.g. Beguería (2003), López-Moreno et al. (2011).

The volumetric quantification of hydrological deficit (D) as result of the difference between volume of precipitation $(\mathrm{P})$ and volume of water at the reservoir entrance of $(\mathrm{Q})$ was calculated as follows:

a. The 1955-2015 period was divided into 6 decennial intervals (1955-65), (1966-75), ..., (2006-2015) with the aim of improving operability with GIS processing and to be able to make comparisons with periods of land cover change.

b. For each of these periods, the annual average of $P$ was calculated. The PET was also calculated using the Thornthwaite method from temperature and latitude data to get a maximum upper limit of evapotranspiration (ET), not the real ET (RET).

c. The P and PET altitudinal gradient was calculated by means of a linear regression for the interval of each decennial year, hence resulting in six gradients in total for $\mathrm{P}$ and another six for PET.

d. Using a $5 \mathrm{~m}$ pixel Digital Elevation Model and GIS software, the gradient of P and PET was applied to each pixel value to obtain P and PET models for each decade. 
e. Two more digital models were calculated from the residual values in the linear regression using an IDW interpolation. These models were those mentioned in the previous paragraph and were used in order to improve fidelity. This type of GIS modelling has been used previously in climate analysis (Fernández-García, 1995; Ninyerola et al. 2010; Modallaldoust et al. 2008; Cañada et al. 2012).

f. Finally, the sum was calculated of the pixel values of the two resulting models of $P$ and PET in each time period and the result was converted to $\mathrm{hm}^{3}$, ready to be compared with the water flow data from the same periods (Q).

The third block of results corresponds to the analysis of sedimentary yield trends through a lithostratigraphic profile in a lacustrine deposit inside the Requejada reservoir (42 $55^{\prime} 13.60^{\prime \prime} \mathrm{N}$, $\left.4^{\circ} 29^{\prime} 14.94 " W\right)$. Evolutive samples were collected when the reservoir was almost empty at the end of the summer in 2016. The granulometric analysis of the fine fraction was performed in the laboratory, where samples were prepared following the recommendations proposed by (Vaudour, 1979). Sands and silts were separated according to groups of grain diameter. Each group was weighed to construct a frequency distribution and the results were interpreted through logarithmic distribution graphs of grain size diameter according to the Krumbein (1934) phi scale following some of the statistical parameters improved by Folk and Ward (1957). The organic matter content was also calculated using the loss of ignition method, which consists of weighing a sample of sediment before and after the combustion period (Gale and Hoare, 1991).

\section{Results}

\subsection{Land cover evolution}

Land cover analysis clearly shows an increase in forest and shrubs following the collapse of the traditional agrarian system and the beginning of the demographic decline (Error! Reference source not found.) leading to a fall in the area covered by crops and grasslands (Figure 2). 
124 Forests and shrubs covered $18 \%$ of the land in the mid- $20^{\text {th }}$ century, but this figure has now 125 increased to $60 \%$. The extension of Grasslands, which were the basis of the economy sustained 126 by stockbreeding, fell from $54 \%$ of the total area to $16 \%$ over the same period.

127 Nevertheless, this transformation of the landscape by the change in land use did not happen 128 linearly in time. Forest cover quickly increased between 1955 and 1972 (Figure 4) and 129 subsequently stabilized. Meanwhile, shrub areas grew consistently at the same rate, which 130 was also the rate at which grasslands diminished.

131 In general, several episodes of behavior can be identified in the vegetation cover and linked to 132 three spatial structures of land use. Firstly, grassland use was dominant in terms of extension, 133 forest was secondary land cover, and shrubs and crops shared the remaining space in almost equal parts. Stockbreeding, forestry, and agriculture took up nearly the entire territory. This land use structure had been in place since the $10^{\text {th }}$ century, transforming hydrological and geomorphological processes.

The same distribution of grasslands, forest and shrubs define a second land use structure between the 60's and 90's, in which the main difference is the significant growth of shrubs and forest extension and the complete disappearance of crops. It is a 30-year period of transition during which abandonment took place following depopulation. Croplands turned into grasslands in the best areas located near the villages, while shrubs or young oak tree forests took over in the lower quality ones. Vegetation cover also increased in the high-altitude grassland areas, where shrubs and Quercus sp. forests, which had the best capacity to adapt, advanced to colonize high mountain pasturing areas no longer used by transhumance, in a long-lasting process that began in the $19^{\text {th }}$ century.

Finally, over the last 20 years a new land use structure has arisen as result of these changes. 
decreased, a fact which will be discussed later. The land use structure of the area studied presents a trend towards equilibrium between a reduced percentage of grasslands in the bottom of the valleys and a dominant mosaic of forest and shrubs on slopes.

\subsection{Climate and water resource trends.}

152

There is a considerable annual water flow decrease at a rate of $0.97 \mathrm{hm}^{3} /$ year since 1956 , which means a $21.3 \%$ total drop since records began (Error! Reference source not found.3). This contrasts with the evolution of precipitation, for which there is an absence of any significant trend. Precipitation shows variability among decades with positive anomalies in the 1970s and negative ones in the 1980s and 1990s. Thereafter positive anomalies tend to dominate but with high interannual variability. The evolution of temperatures is different. There is a statistically significant $1.5^{\circ} \mathrm{C}$ increase since 1955 , which correspons to a 0.023 ${ }^{\circ} \mathrm{C} /$ year rate.

Residuals in the linear regression between annual climatic data ( $\mathrm{P}$ and $\mathrm{T}$ ) and water flow (Error! Reference source not found.3 and Table 2) show strong positive anomalies during the 1960 s, whereas negative values are concentrated in the 1980s and 1990s. There is a subsequent fall in the magnitude of residuals until the present, although they remain mainly negative. This means that almost every year since the 1960s the real water flow should be lower than the calculated value. In other words, according to the climate parameters $(P, T)$ observed, the real water flow should be higher.

The growth of the hydrological deficit (D) between 1955 and 1995 was not always explained by temperatures. In the period 1975-1995, D increased even when PET decreased, and precipitations showed a clear increase, especially between 1975 and 1985. Table 3 and Figure 4 show that the volume of accumulated annual water flow decreased and that it fails to match the total precipitation volume until after 1995. The PET would not be able to offset the water flow loss even at its highest scenario (PET = Real Evapotranspiration). Even during the period 
173 with the highest temperature increase (1995-2005), the PET increased by $9.5 \mathrm{hm}^{3}$ and water

174 flow decreased by $31.3 \mathrm{hm}^{3}$. From 1995 onwards a more stable period came and D showed a 175 relative fall.

176

177

178

179

180

181

182

183

184

185

\subsection{Sediment yield evolution}

The study of the lacustrine deposit inside the reservoir (Figure 5) facilitated the calculation of landfill of $151 \mathrm{~cm}$ over a period of 75 years. Since 1940, the year the reservoir came into operation, it has been possible to check for any changes in grain size and composition. Even though clay is well represented throughout the profile since this is a lacustrine sedimentation environment, the general trend for the period studied shows a clear evolution from coarse to fine material, from a higher percentage of sands to a higher proportion of silt and clay (Figure 5). The median shift in the frequency distribution shows a change from a grain size of $1.1 \mathrm{~mm}$ in the $1940 \mathrm{~s}$ to $0.8 \mathrm{~mm}$ in the most recent layers.

There are no well defined contacts between layers anywhere in the profile. Stability is quite clear in the center of the profile (CA-5 A-B-C). In contrast, the upper layers show more marked contacts. These possess layers with more irregular sand grain sizes though these follow a decreasing trend, except in layers (CA-6, CA-8 and CA-10).

The proportion of organic matter following an equilibrium period (CA-1 to CA-7) increased exponentially in the profile from the CA-8 layer to CA-10. At that point a slight decrease is seen at the top of the profile. The exponential increase in organic matter coincides with the abrupt fall in the evolution of grain size anomalies.

Grain-size showed a decreasing trend as indicated by the median anomalies that exhibited a sharp change from the CA-7 layer onwards, which fits the change in the negative water flow anomalies from the 1980s (Figure 3) until the present. Sediment depth, which has been subject to this dynamic, is just $55 \mathrm{~cm}, 36 \%$ of the total section. 


\section{Discussion}

198

199

200

201

202

203

204

205

206

207

208

209

210

A continuous reduction in water flow is observed in the Requejada reservoir since its construction. Such a trend cannot be explained away just by the evolution in precipitation, since this has not exhibited significant trends during the study period. In the meantime, shrubland and tree spices (especially Quercus pyrenaica) have extended on ancient crops and grasslands close the settlements and beyond into subalpine areas. Meanwhile, there has been a clear fall in the summer cattle and sheep-breeding economy. The increase in temperatures helped this process, which has extended the subalpine zone vertically at the expense of the alpine zone (Figure 2). The implications of these dynamics in water runoff are not clear here. Nevertheless, García-Ruiz et al. (1995), who studied the land changes caused by abandonment on different land covers in the Pyrenees, found that high mountain abandoned grasslands areas suffer the highest erosion rates during the first 10 years after abandonment and reach another peak of erosion between 25 and 50 years after abandonment, which is related to shrub degradation. Therefore, they conclude that grasslands are the best erosion-preventive land cover while still permitting significant water runoff. They explained this assertion by examining their catchment runoff model residuals, which were at their height during the 1960s, the moment when most of the pasture was recovering thanks to decreasing livestock pressure. In our area, 1955-1956 was the decade with the most extensive grassland cover, which has decreased thereafter due to shrubland progress (Figure 2).

Bearing in mind that water extraction for human use has always been negligible in this catchment, we see here the imprint from vegetation change. Vegetation is known to have a high-water storage and runoff reduction capacity, although this process is not a linear function of its growth (García-Ruiz et al. 1995). The initial vegetation spread over the old crop plots quickly, provoking a higher hydrological deficit than in all the subsequent years of forest densification (Figure 4). This fact has been proved elsewhere, especially in the Pyrenees, a 
222 mountain range that suffered the same land abandonment dynamics (Beguería et al.,2003;

223 García-Ruiz et al., 2015; Lasanta et al., 2010; López-Moreno et al., 2014; Sanjuán et al., 2014;

224 Tasser and Tappeiner, 2002; Vicente-Serrano et al., 2014, 2004).

225 Temperature has shown statistically significant warming, which had already been observed in 226 previous research (Ortega and Morales, 2015). This increase has a big impact over the water 227 flow especially in the period 1995-2005, although it is not large enough to justify the trends 228 before this period (Figure 4).

229 Sediment yield decreased immediately after shrub extension on grasslands and crop plots, as 230 already pointed out by many authors (Liébault and Piégay, 2002, Keesstra et al., 2005; Molina 231 et al., 2009; Wohl, 2015). The sediment load on streams is doubtlessly linked to erosion, which 232 is in decline in the catchment due to the termination of activities that greatly altered soil conditions and vegetation cover, such as coal mining (ended between 1970s - 1990s), agriculture (ended between 1940s - 1970s) and stockbreeding. Summer transhumant stockbreeding was dominant in this area but gradually declined between the $19^{\text {th }}$ century and the 1990s. This activity could modify landscapes and geosystems on its own (Bertrand, 1984; Bertrand and Bertrand, 1986) by increasing erosion and sediment yield, which was already documented and triggered some alarms in the late 1950s (Nossin, 1959).

That situation has now been changed and erosion is no longer a problem. Vegetation covers screes, gullies, naked ground and river banks. In this context, an exponential increase in the water-transported organic matter content was found in the catchment landfill. This situation can be explained by the more extensive and denser vegetation cover in the catchment, but it may also have happened due to a relative mass loss of non-organic matter in the profile due to lixiviation or greater water exposure to the atmosphere during the summer drought, which would have favored algal bloom. 
246 This comprehensive scale study of the basin allows us to check the hypothesis that there are

247 elements playing a decisive role in runoff beyond the balance of temperature and

248 precipitation. Among these changes, those of vegetation cover that can be fitted using new

249 practices of use and their management to regulate runoff, hydric resources, erosion and

250 sedimentation in depopulated areas stand out. The effectiveness that extensive livestock

251 farming has had throughout history in the Cantabrian Mountains on determining vegetation

252 cover has been checked, and given that depopulation and abandonment are generalized,

253 recovering the role of this industry for the purposes of land management may be a useful and

254 replicable decision.

255 5. Conclusions.

256 Runoff in the Pisuerga catchment has fallen by $21,3 \%$ since the mid- $20^{\text {th }}$ century despite the

257 lack of precipitation trends for the same period. Temperature has increased by $1,5^{\circ} \mathrm{C}$, but this

258 cannot fully explain the sharp reduction in water flow. Water extraction for human use is

259 negligible in the catchment, hence this trend must have been caused by a combination of

260 increased interception, and actual evapotranspiration associated to forest growth and shrub

261 expansion.

262

Impacts of increasing vegetation on runoff generation have not been linear. The response of water yield was more intense immediately after abandonment. Since the 1990s land cover changes have stabilized.

265

Runoff reduction clearly impacts geomorphological activity making erosion, transport, and sedimentation processes less powerful. This in turn leads to smaller sized sediments at the outlet of the catchment and a general stabilization on slopes and river margins. 
This research was financed by the MECD through the FPU13/05837 grant and supported by the

CGL2015-68144-R Project from the MINECO-FEDER program. We also wish to thank Manuel

Gómez, Patricia Fidalgo, Alberto Merino, Raúl Gutiérrez, and Víctor Martínez for their help in

the fieldwork.

\section{References}

Beguería, S., López-Moreno, J.I., Lorente, A., Seeger, M., García-Ruiz, J.M., 2003. Assessing the effect of climate oscillations and land-use changes on streamwater flow in the Central Spanish Pyrenees. AMBIO J. Hum. Environ. 32, 283-286.

Bertrand, C., Bertrand, G., 1986. La végétation dans le géosystème. Phytogéographie des montagnes cantabriques centrales (Espagne). Rev. Géographique Pyrén. Sud-Ouest 57, 291312. doi:10.3406/rgpso.1986.4949

Bertrand, G., 1984. Apogée et déclin d'un géosystème sylvo-pastoral (Montagne de León et de Palencia, Espagne du nord-ouest). Rev. Géographique Pyrén. Sud-Ouest 55, 239-248.

Cañada, M.R., Gallego, G., Fernández, F., 2012. Análisis de las disponibilidades hídricas en las cuencas hidrográficas de la Comunidad de Madrid: situación actual y previsiones futuras. Territoris.

Castaño, J., 2015. El libro de los pesos y medidas. La Esfera de los Libros, 620.

Ceballos-Barbancho, A., Morán-Tejeda, E., Luengo-Ugidos, M.Á., Llorente-Pinto, J.M., 2008. Water resources and environmental change in a Mediterranean environment: The south-west sector of the Duero river basin (Spain). J. Hydrol. 351, 126-138. https://doi.org/10.1016/j.jhydrol.2007.12.004

CHD, 2015. Plan Hidrológico de la parte española de la demarcación hidrográfica del Duero. 2015-2021.

Church, M., Burt, T., Galay, V., Kondolf, M., 2009. Rivers, in: Geomorphology and Global Environmental Change. Cambridge University Press, NY.

Fernández-García, F., 1995. Manual de climatología aplicada: clima, medio ambiente y planificación, Espacios y sociedades. Serie mayor. Síntesis, Madrid.

Folk, R.L., Ward, W.C., 1957. Brazos River bar: a study in the significance of grain size parameters. J. Sediment. Res. 27.

Gallart, F., Llorens, P., 2004. Observations on land cover changes and water resources in the headwaters of the Ebro catchment, Iberian Peninsula. Phys. Chem. Earth 11-12, 769-773.

Gale, S.J., Hoare, P.G., 1991. Quaternary sediments: petrographic methods for the study of unlithified rocks. Belhaven Press New York. 
García-Ruiz, J.M., Lasanta, T., Ortigosa, L., Ruiz-Flaño, P., Martí, C., González, C., 1995. 315 Sediment Yield under Different Land Uses in the Spanish Pyrenees. Mt. Res. Dev. 15, $229-240$.

doi:10.2307/3673930

García-Ruiz, J.M., Lana-Renault, N., Beguería, S., Lasanta, T., Regüés, D., Nadal-Romero, E., Serrano-Muela, P., López-Moreno, J.I., Alvera, B., Martí-Bono, C., Alatorre, L.C., 2010. From plot to regional scales: Interactions of slope and catchment hydrological and geomorphic processes in the Spanish Pyrenees. Geomorphology 120, 248-257. doi:10.1016/j.geomorph.2010.03.038

García-Ruiz, J.M., López-Moreno, J.I., Vicente-Serrano, S.M., Lasanta-Martínez, T., Beguería, S., 2011. Mediterranean water resources in a global change scenario. Earth-Sci. Rev. 105, 121139. doi:10.1016/j.earscirev.2011.01.006

García-Ruiz, J.M., López-Moreno, J.I., Lasanta, T., Vicente-Serrano, S.M., González-Sampériz, P., Valero-Garcés, B.L., Sanjuán, Y., Beguería, S., Nadal-Romero, E., Lana-Renault, N., Gómez-Villar, A., 2015. Los efectos geoecológicos del cambio global en el Pirineo Central español: una revisión a distintas escalas espaciales y temporales. Pirineos 170, e012.

Good, S.P., Noone, D., Bowen, G., 2015. Hydrologic connectivity constrains partitioning of global terrestrial water fluxes. Science 349, 175-177. doi:10.1126/science.aaa5931

Goudie, A.S., 2013. The Human Impact on the Natural Environment: Past, Present, and Future, 7, Wiley-Blackwell.

Keesstra, S.D., Van Huissteden, J., Vandenberghe, J., Van Dam, O., De Gier, J., Pleizier, I.D., 2005. Evolution of the morphology of the river Dragonja (SW Slovenia) due to land-use changes. Geomorphology 69, 191-207.

Krumbein, W.C., 1934. Size Frequency Distributions of Sediments. J. Sediment. Res. 4.

Lasanta, T., Nadal, E., Serrano-Muela, M.P., Vicente-Serrano, S.M., García-Ruiz, J.M., others, 2010. Escorrentía y erosión tras el abandono de tierras de cultivo en montaña: resultados de la Estación Experimental "Valle de Aísa." Pirineos 165, 115-133.

Liébault, F., Piégay, H., 2002. Causes of 20th century channel narrowing in mountain and piedmont rivers of southeastern France. Earth Surf. Process. Landf. 27, 425-444.

López-Moreno, J.I., Beguería, S., García-Ruiz, J.M., 2006. Trends in high water flows in the central Spanish Pyrenees: response to climatic factors or to land-use change? Hydrol. Sci. J. 51, 1039-1050.

López-Moreno, J.I., Vicente-Serrano, S.M., Morán, E., Zabalza, J., Lorenzo, J., García-Ruiz, J.M., 2011. Impact of climate evolution and land use changes on water yield in the ebro basin. Hydrol. Earth Syst. Sci. 15, 311-322. doi:10.5194/hess-15-311-2011

López-Moreno, J. I., Zabalza, J., Vicente-Serrano, S.M., Revuelto, J., Gilaberte, M., Azorín, C., Morán, E., García-Ruiz, J.M., Tague, C., 2014a. Impact of climate and land use change on water availability and reservoir management: Scenarios in the Upper Aragón River, Spanish Pyrenees. Sci. Total Environ. 493, 1222-1231. doi:10.1016/j.scitotenv.2013.09.031

Marsh, G.P., 1864. Man and Nature, Or Physical Geography as Modified by Human Action by George P. Marsh. Sampson Low, Son and Marston. 
Modallaldoust, S., Bayat, F., Soltani, B., Soleimani, K. 2008. Applying Digital Elevation Model to Interpolate Precipitation. Journal of Applied Sciences, 8: 1471-1478.

Madoz, P., 1850. Diccionario Geográfico Estadístico Histórico, 1845-1850, Facsimil. ed. Ámbito ediciones, Valladolid.

Molina, A., Govers, G., Cisneros, F., Vanacker, V., 2009. Vegetation and topographic controls on sediment deposition and storage on gully beds in a degraded mountain area. Earth Surf. Process. Landf. 34, 755-767.

Morán-Tejeda, E., Ceballos-Barbancho, A., Llorente, J.M., 2010. Hydrological response of Mediterranean headwaters to climate oscillations and land-cover changes: The mountains of Duero River basin (Central Spain). Glob. Planet. Change 72, 39-49. doi:10.1016/j.gloplacha.2010.03.003

Pereira, H.M., Navarro, L.M., 2015. Rewilding european landscapes. Springer.

Ninyerola, M., Pons, X., Roure, J.M., 2000. A methodological approach of climatological modelling of air temperature and precipitation through GIS techniques. Int. J. Climatol. 20, 1823-1841.https://doi.org/10.1002/1097-0088(20001130)20:14<1823:AID-JOC566>3.0.CO;2-B

Nossin, J.J., 1959. Geomorphological aspects of the Pisuerga drainage area in the Cantabrian Mountains (Spain). Leidse Geol. Meded. 24, 283-406.

Ortega, M.T., Morales, C.G., 2015. El clima de la Cordillera Cantábrica castellano-leonesa: diversidad, contrastes y cambios. Investig. Geográficas 63, 45-67.

Sanjuán, Y., Gómez-Villar, A., Nadal, E., Álvarez-Martínez, J., Arnáez, J., Serrano-Muela, M.P., Rubiales, J.M., González-Sampériz, P., García-Ruiz, J.M., 2014. Linking Land Cover Changes in the Sub-Alpine and Montane Belts to Changes in a Torrential River n/a-n/a. doi:10.1002/ldr.2294

Sanmiguel, A., Morán, E., Alonso-González, E., López-Moreno, J.I., 2017. Effect of snow on mountain river regimes: an example from the Pyrenees. Front. Earth Sci. 1-16.

Sauer, C.O., 1925. The Morphology of Landscape. University of California Publications in Geography. Los

Slaymaker, O., Embleton-Hamann, C., 2009. Geomorphology and Global Environmental Change. Cambridge University Press.

Tasser, E., Tappeiner, U., 2002. Impact of land use changes on mountain vegetation. Appl. Veg. Sci. 5, 173-184.

Thomas, W.L., 1956. Man's Role in Changing the Face of the Earth. Chic. Lond. 10-13.

Turner, B.L., 1990. The earth as transformed by human action: global and regional changes in the biosphere over the past 300 years. CUP Archive.

Vaudour, J., 1979. La région de Madrid, altérations, sols et paléosols: contribution à l'étude géomorphologique d’une région méditerranéenne semi-aride. Éd. Ophrys, Gap, France. 
Vicente-Serrano, S.M., Lasanta, T., Romo, A., 2004. Analysis of spatial and temporal evolution of vegetation cover in the Spanish Central Pyrenees: role of human management. Environ.

Vicente-Serrano, S.M., López-Moreno, J.I., Beguería, S., 2014. Hidrología ambiental: el papel de la gestión humana del territorio en el ciclo hidrológico continental y en los recursos hídricos, in: Geoecología, Cambio Ambiental Y Paisaje: Homenaje Al Profesor José María García Ruiz. Instituto Pirenaico de Ecología, pp. 143-172.

Vitousek, P.M., 1992. Global Environmental Change: An Introduction. Annu. Rev. Ecol. Syst. 23, $1-14$.

Wohl, E., 2015. Legacy effects on sediments in river corridors. Earth-Sci. Rev. 147, 30-53.

Table 1. Meteorological stations used in the study

\begin{tabular}{|c|c|c|c|c|c|c|}
\hline Station & $\begin{array}{l}\text { Locatic } \\
\text { UTM, }\end{array}$ & $\begin{array}{l}(x, y) \\
\text { ETRS } 89\end{array}$ & Altitude & Type & Period & Observations \\
\hline Requejada & 375123 & 4751856 & 1024 & $\mathrm{P}, \mathrm{T}$ & $1961-2014$ & \\
\hline Sta. M. Redondo & 382986 & 4760666 & 1200 & $\mathrm{P}$ & $1955-2014$ & Snowfall days \\
\hline Polentinos & 375411 & 4755245 & 1245 & $\mathrm{P}$ & $1965-2014$ & \\
\hline Lores & 374966 & 4761888 & 1210 & & 1967-2009 & \\
\hline Cervera & 377529 & 4746875 & 1013 & $\mathrm{P}, \mathrm{T}$ & $1955-2014$ & $10 \mathrm{~km}$ out \\
\hline El Campo & 376846 & 4759385 & 1185 & $P, T$ & $1968-2002$ & \\
\hline
\end{tabular}

435

Table 2. Summary of correlation results between series of water flow (Q), precipitation $(P)$ and temperature $(T)$

\begin{tabular}{|c|c|c|c|c|c|c|}
\hline & & Correlations & & & & \\
\hline & & & Year & $Q$ & & \\
\hline & & Correlation Coefficient & 1 & $-0,407$ & & \\
\hline & & Sig (2-tailed) & & 0,002 & & \\
\hline & & $\mathrm{N}$ & 62 & 57 & & \\
\hline Spearman's rho & & & & & & \\
\hline & & Correlation Coefficient & $-0,407$ & 1 & & \\
\hline & & Sig (2-tailed) & 0,002 & & & \\
\hline & & $\mathrm{N}$ & 57 & 57 & & \\
\hline ** Correlation is $\mathrm{s}$ & icant at the & 0,01 level (2-tailed) & & & & \\
\hline & & & efficients & & & \\
\hline & & $\begin{array}{r}\text { Unstandardized } \\
\text { Coefficients }\end{array}$ & & $\begin{array}{r}\text { Standardized } \\
\text { Coefficients }\end{array}$ & & \\
\hline Model & & B & Std. Error & Beta & $\mathrm{t}$ & Sig. \\
\hline 1 & Constant & 0,028 & 0,109 & & 0,26 & 0,796 \\
\hline & $P$ & 0,728 & 0,125 & 0,629 & 5,831 & 0 \\
\hline 2 & Constant & 0,034 & 0,099 & & 0,343 & 0,733 \\
\hline & $\mathrm{P}$ & 0,665 & 0,114 & 0,574 & 5,812 & 0 \\
\hline
\end{tabular}


Dependent Variable: $\mathbf{Q}$

Table 3.Values of volumetric quantification of water resources retained in the catchment

\begin{tabular}{|c|c|c|c|c|c|c|c|c|c|c|c|c|c|}
\hline & $\begin{array}{c}P \\
\left(h m^{3}\right)\end{array}$ & $P * *$ & $\begin{array}{c}Q \\
\left(h m^{3}\right)\end{array}$ & $Q^{* *}$ & $\begin{array}{c}D=(P-Q) \\
\left(h m^{3}\right)\end{array}$ & $D^{* *}$ & $\begin{array}{c}\text { PET } \\
\left(\mathrm{hm}^{3}\right)\end{array}$ & PET* & $\begin{array}{l}\text { P Mean } \\
(\mathrm{mm})\end{array}$ & $\begin{array}{c}\text { P Desv.st } \\
\text { (mm) }\end{array}$ & $A$ & $B$ & $r^{2}$ \\
\hline 1955 - 1965 & 253,4 & $-0,28$ & 184,4 & 1,08 & 64,5 & $-1,85$ & 139,8 & 1,80 & 999,69 & 146,85 & 0,77 & 97,3 & 0,31 \\
\hline 1966 - 1975 & 271,9 & 1,05 & 184,8 & 1,10 & 84,4 & $-0,60$ & 129,4 & $-0,44$ & 1012,46 & 165,67 & 0,85 & 13,5 & 0,33 \\
\hline 1976 - 1985 & 280,5 & 1,66 & 171,6 & 0,46 & 105,7 & 0,74 & 129,1 & $-0,49$ & 1035,39 & 157,23 & 0,86 & 29,7 & 0,29 \\
\hline 1986 - 1995 & 248,9 & $-0,60$ & 140,3 & $-1,07$ & 113,9 & 1,26 & 125,4 & $-1,30$ & 1022,38 & 149,97 & 0,76 & 133,6 & 0,22 \\
\hline 1996 - 2005 & 246,2 & $-0,80$ & 146,9 & $-0,75$ & 97,4 & 0,22 & 134,9 & 0,75 & 952,04 & 155,57 & 0,90 & $-106,8$ & 0,34 \\
\hline 2006 - 2016 & 243,0 & $-1,03$ & 145,1 & $-0,83$ & 97,5 & 0,23 & 129,9 & $-0,32$ & 999,69 & 155,16 & 0,47 & 449,8 & 0,25 \\
\hline
\end{tabular}

P: Precipitation; ** Anomalies; D: Hydrological deficit; Q: Water flow; PET: Potential Evapotranspiration; A \& B: Coefficients linear regression; $r^{2}$ : Pearson's number

439 


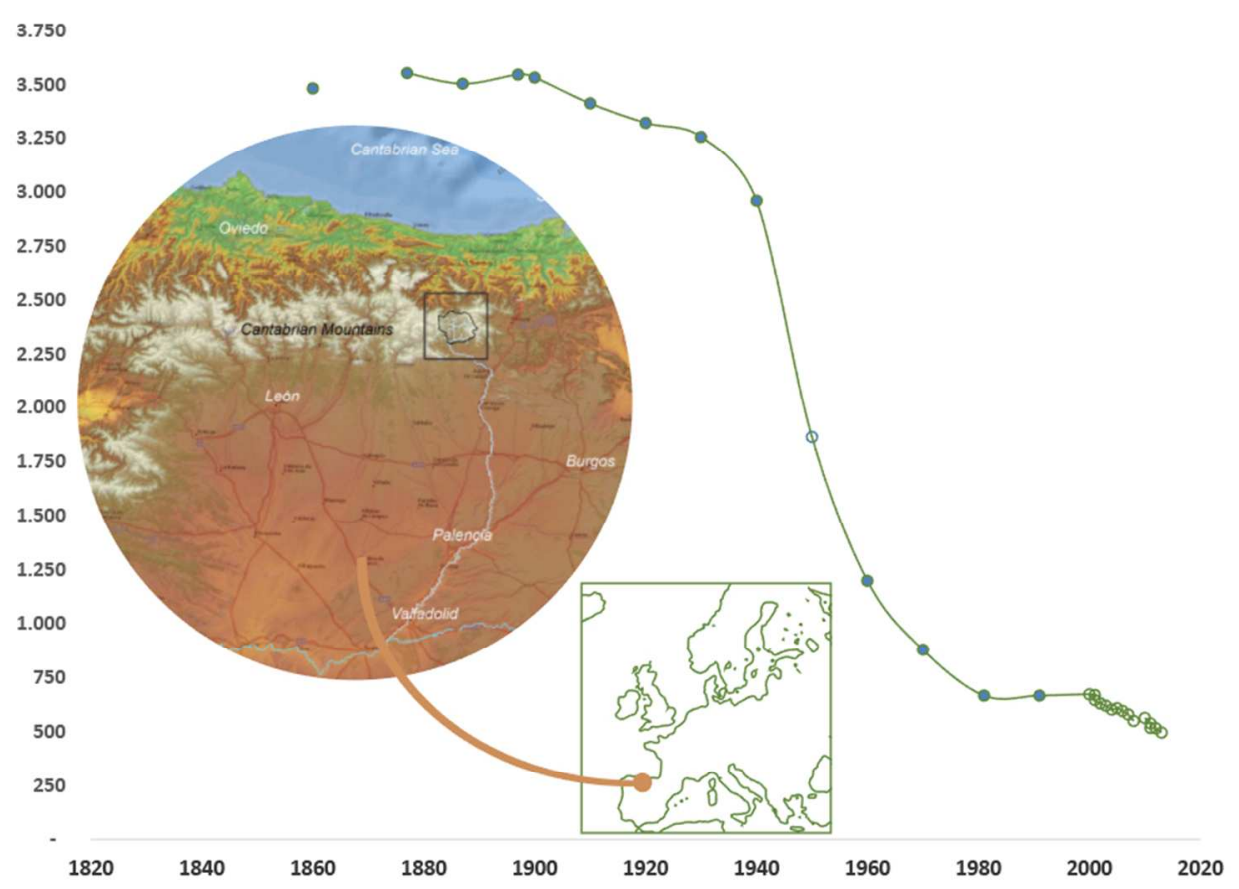

Figure 1. Location map and population evolution since trustworthy sources exist. Source: Instituto Nacional de Estadística de España (INE) census and Diccionario Geográfico Estadístico de Pascual Madoz (Madoz, 1850) 

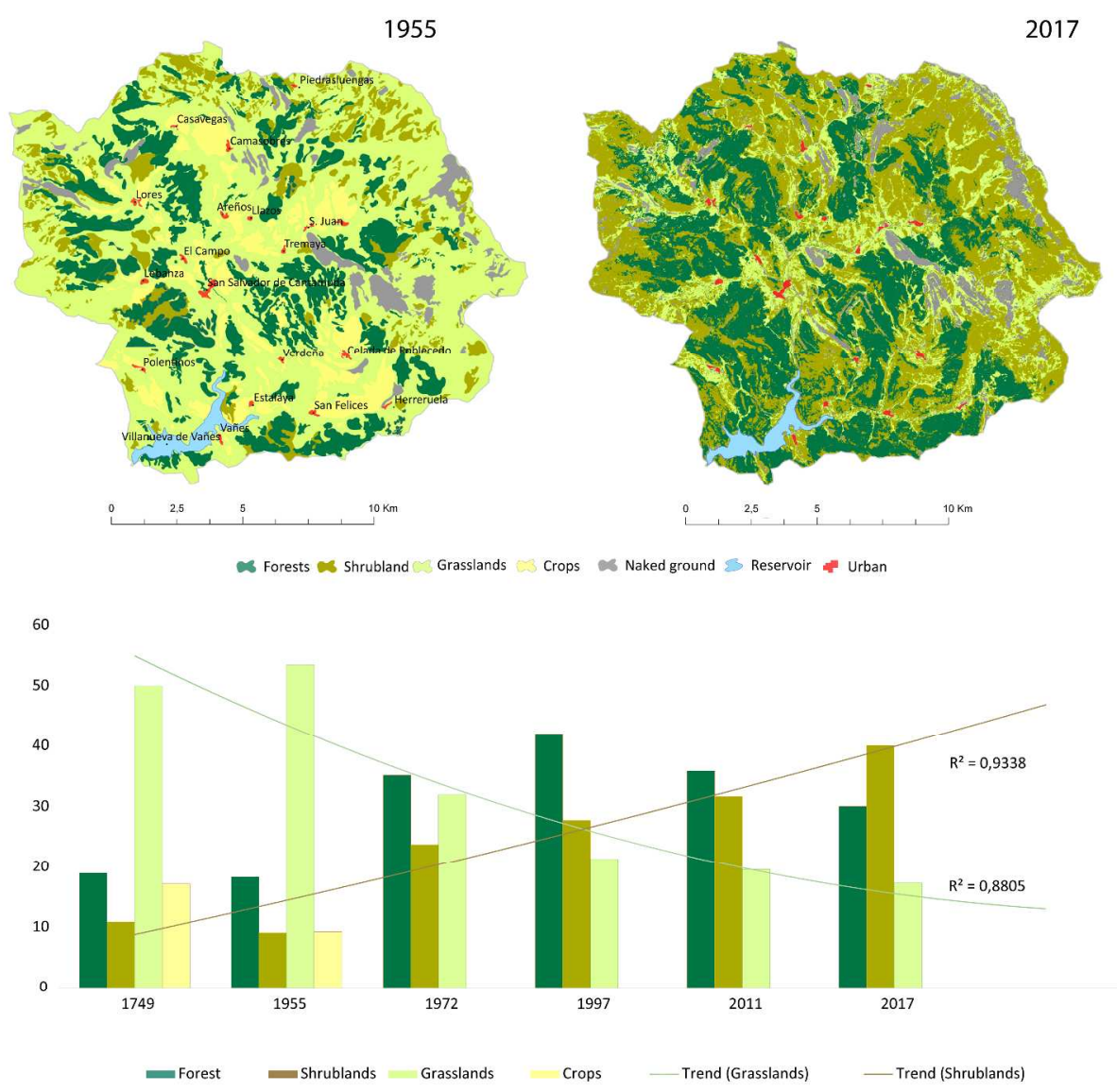

Figure 2. Land cover evolution since 1749 
(A)

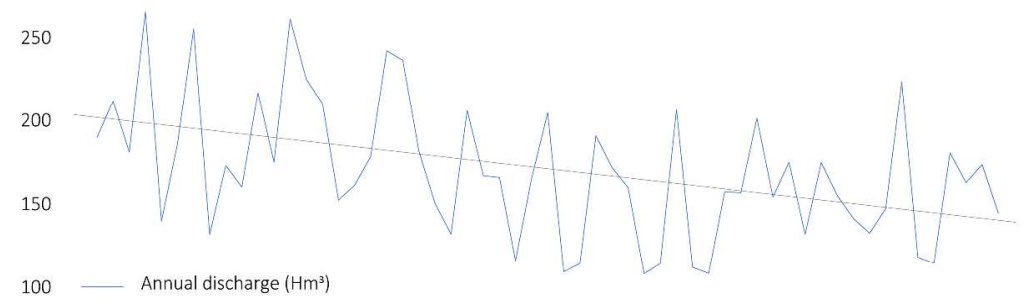

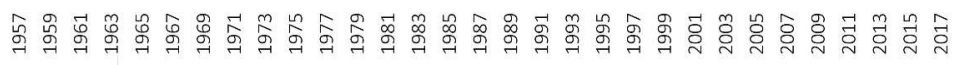

(B)

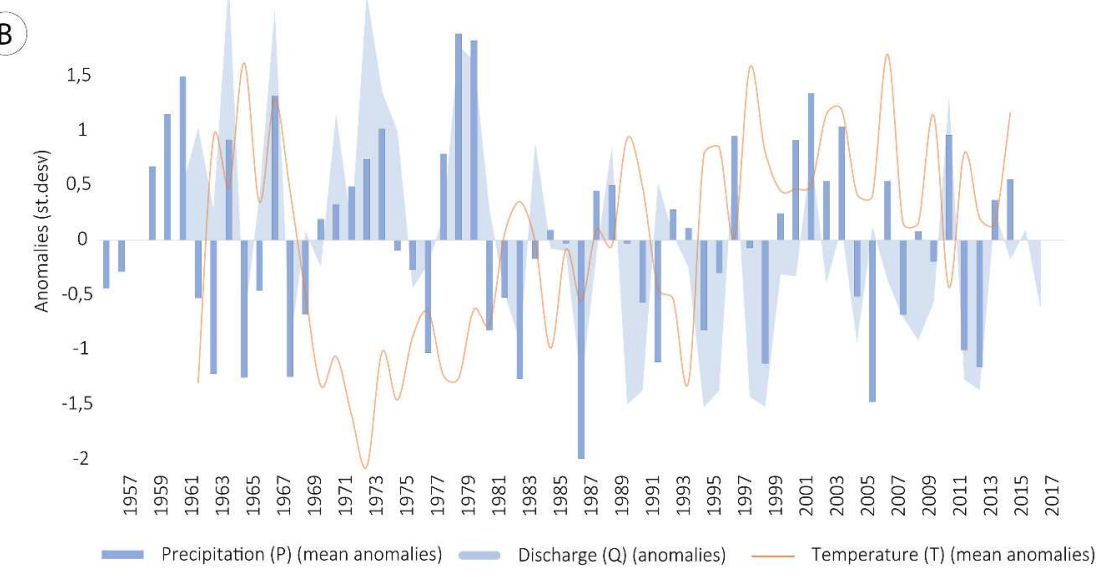

$$
\begin{aligned}
& \text { (C) } 2,5
\end{aligned}
$$

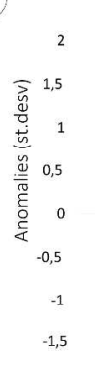

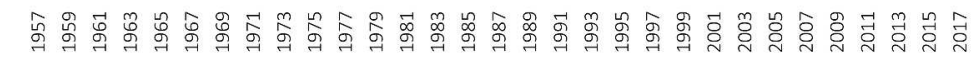

Figure 3. A) Annual water flow evolution in $\mathrm{hm}^{3}$ between (1956 and 2016). B) Evolution of regional series of precipitation, temperature, and water flow. C) Evolution of residual values from linear regressions among precipitation, temperature, and water flow. This graph allows the years in which climate parameters are able or unable to explain the water flow to be identified. 


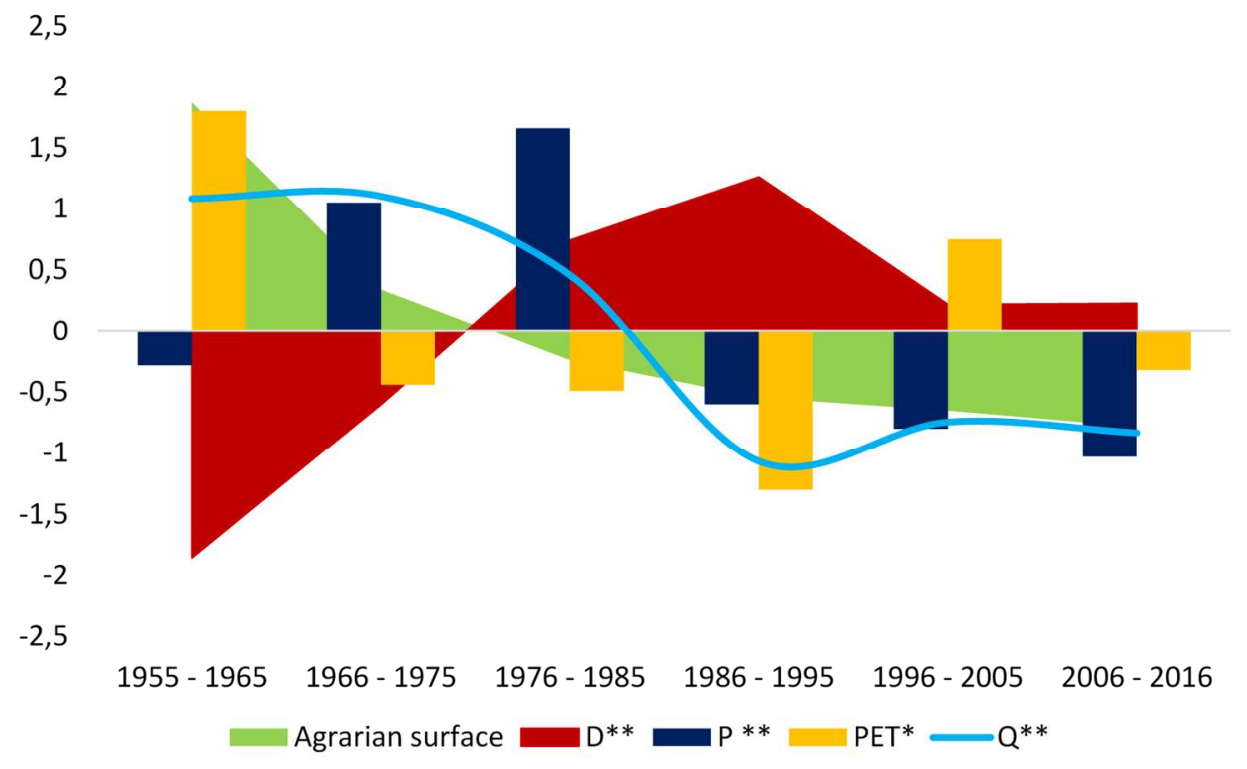

Figure 4. Comparative evolution of climate parameters (P, ETP), water flow (Q), hydrological deficit (D) and agrarian surface (mostly pastures). 


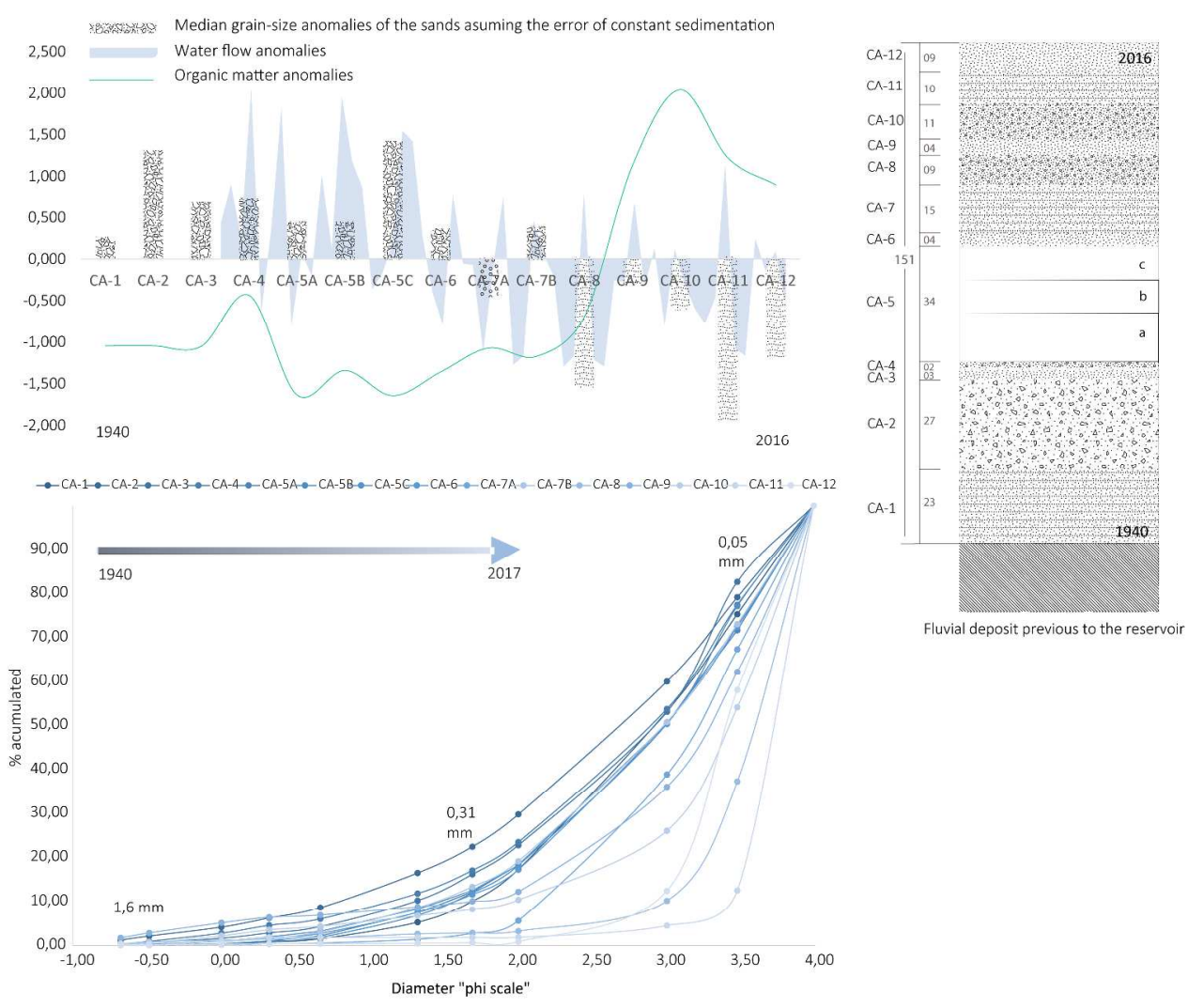

Figure 5. Sedimentological changes on the Requejada reservoir deposit (1940 - 2016). Top left of the figure, comparison between trends in grain size, water flow, and organic matter; top right, texture composition of the deposit; bottom, sands size distribution the timespan 